\title{
DNA damage by ochratoxin $A$ in rat kidney assessed by the alkaline comet assay
}

D. Želježić, A.-M. Domijan and M. Peraica
Institute for Medical Research and Occupational Health, Zagreb, Croatia

\author{
Correspondence \\ A.-M. Domijan \\ Institute for Medical Research \\ and Occupational Health \\ Ksaverska c. 2 \\ 10001 Zagreb \\ Croatia \\ Fax: +385-1-4673-303 \\ E-mail: adomijan@imi.hr \\ Research supported by the \\ Mutagenesis Unit, Institute for \\ Medical Research and Occupational \\ Health and by the Ministry of \\ Science, Education and Sports of \\ the Republic of Croatia.
}

Received September 12, 2005 Accepted August 29, 2006

\begin{abstract}
There are few studies of ochratoxin A (OTA) genotoxicity in experimental animals and the results obtained with cell cultures are inconsistent, although the carcinogenic potential of OTA for the kidney of experimental animals has been well established. We studied the genotoxic potential of OTA in the kidney of adult female Wistar rats (5 in each group) treated intraperitoneally with OTA $(0.5 \mathrm{mg} \mathrm{kg}$ body weight ${ }^{-1}$ day $^{-1}$ for 7,14 , and 21 days) measuring DNA mobility on agarose gel stained with ethidium-bromide using standard alkaline single-cell gel electrophoresis (comet assay). Negative control animals were treated with solvent (Tris buffer, $1.0 \mathrm{mg} / \mathrm{kg}$ ) and positive control animals were treated with methyl methanesulfonate $(40 \mathrm{mg} /$ $\mathrm{kg}$ ) according to the same schedule. OTA concentrations in plasma and kidney homogenates in 7-, 14-, and 21-day treated animals were $4.86 \pm 0.53,7.52 \pm 3.32,7.85 \pm 2.24 \mu \mathrm{g} / \mathrm{mL}$, and $0.87 \pm 0.09,0.99 \pm$ $0.06,1.09 \pm 0.15 \mu \mathrm{g} / \mathrm{g}$, respectively. In all OTA-treated groups, the tail length, tail intensity, and tail moment in kidney tissue were significantly higher than in controls $(\mathrm{P}<0.05)$. The tail length and tail moment were higher after 14 days than after 7 days of treatment $(\mathrm{P}<$ $0.05)$, and still higher after 21 days $(\mathrm{P}<0.05)$. The highest tail intensity was observed in animals treated for 21 days, and it differed significantly from animals treated for 7 and 14 days $(\mathrm{P}<0.05)$. OTA concentrations in plasma and kidney tissue increased steadily and OTA concentration in kidney tissue strongly correlated with tail intensity and tail moment values. These results confirm the genotoxic potential of OTA, and show that the severity of DNA lesions in kidney correlates with OTA concentration.
\end{abstract}

\section{Introduction}

Ochratoxin A (OTA) is a mycotoxin produced by some strains of Penicillium and Aspergillus molds that naturally contaminate food and feed under all climatic conditions (1). Humans are exposed to OTA by ingestion of contaminated food of vegetable
Key words - Comet assay

- DNA adducts

- Experimental animals

- Mycotoxin

..................... or animal origin. OTA has been shown to be nephrotoxic, hepatotoxic, immunotoxic, and teratogenic in laboratory animals. Exposure to OTA is believed to cause endemic nephropathy, a fatal human disease affecting some regions of Bosnia and Herzegovina, Bulgaria, Croatia, Romania, and Serbia (2). In endemic regions, a high incidence of other- 
wise rare urothelial tumors has also been attributed to exposure to OTA. It was proven that OTA increases the incidence of uncommon tubular cell adenomas and of tubular cell carcinomas in rats of both sexes in a dose-dependent manner and the incidence and multiplicity of fibroadenomas of the mammary gland in female rats (3). The International Agency for Research on Cancer classified OTA as a 2B group compound (possibly carcinogenic to humans and with sufficient evidence for carcinogenicity in laboratory animals), although the mechanism of its carcinogenicity is not understood (4). It is believed that this assumed OTA carcinogenicity should reflect in DNA changes. The genotoxicity of OTA was tested in various cell lines, but the results were inconclusive (4), probably because routine genotoxicity tests were contrasting, equivocal or negative in compounds whose genotoxic activity depended on tissue-specific mechanisms. Furthermore, the genotoxic activity is organ and tissue specific for compounds with distinct targets for carcinogenicity (5). The genotoxicity of OTA in laboratory animals has been postulated mainly on the basis of the results of ${ }^{32} \mathrm{P}$-postlabeling experiments, which showed OTA-dependent formation of DNA adduct spots $(6,7)$. The single available report on genotoxicity tested by the comet assay in rat kidneys revealed DNA fragmentation, but animals were treated with a single, very high oral OTA dose (10 mg/kg body weight) (8).

The alkaline single-cell gel electrophoresis (comet) assay is a sensitive and powerful method for determining DNA strand breaks and alkali labile sites (oxidative DNA base damage, and DNA-DNA/DNA-protein cross-linking, DNA adducts) at the cell level and has been widely used for genotoxicity studies. Since the comet assay does not require cell cultivation, the genotoxic potential of a substance of interest can be assessed in the cells of specific target tissue. The aim of the present study was to determine the time course of OTA-produced DNA damage by assessing alkali-labile sites using the comet assay in rat kidney tissue.

\section{Material and Methods}

\section{Chemicals}

OTA (99\% purity), $\mathrm{Na}_{2}$ EDTA, methyl methanesulfonate, and the chemicals needed for the comet assay were purchased from Sigma (St. Louis, MO, USA). Tris (hydroxymethyl) aminomethane and $\mathrm{NaCl}$ were from Kemika (Zagreb, Croatia). Water (Merck, Darmstadt, Germany) and methanol (Kemika, Zagreb, Croatia) used for the highperformance liquid chromatography (HPLC) mobile phase were of HPLC grade.

\section{Animal treatment schedule}

Adult female Wistar rats weighing $190 \mathrm{~g}$ maintained on a 12-h light/dark cycle and at a constant temperature of $24^{\circ} \mathrm{C}$ were kept in macrolone cages. Animals were fed a standard diet for laboratory rodents (Pliva, Zagreb, Croatia) and had free access to water. The study was approved by the Ethics Committee of the Institute for Medical Research and Occupational Health, Zagreb, according to current laws of the Republic of Croatia.

The rats were randomly assigned to nine groups of 5 animals each receiving either OTA ( $0.5 \mathrm{mg} / \mathrm{kg}$ body weight) dissolved in Tris buffer or solvent only $(1.0 \mathrm{~mL} / \mathrm{kg}$, negative control animals) intraperitoneally (ip) every day for up to three weeks. The ip treatment was chosen because it is considered to be a valuable tool for clarifying the mechanism of action of mycotoxins (9). Positive control animals were treated with methyl methanesulfonate ( $40 \mathrm{mg} / \mathrm{kg}$ body weight) according to the same schedule.

Twenty-four hours after the 7th, 14th, and 21 st doses, 5 OTA-treated, 5 negative and 5 positive control animals were killed with coal gas. Kidneys were collected, 
washed in saline, and kept on ice until the comet assay and OTA analysis.

\section{OTA analysis}

OTA concentrations in plasma and $10 \%$ kidney homogenate $(0.9 \%$ sterile solution of $\mathrm{NaCl}$ ) were determined by HPLC according to methods described by Peraica et al. (10) and Bauer et al. (11), respectively.

OTA was determined by HPLC (Varian, Walnut-Creek, CA, USA) with fluorescence detection. The guard column and analytical column were LiChrospher RP-18 (Merck, Darmstadt, Germany) 4.0 x 4.0 and 125.0 x $4.0 \mathrm{~mm}$, respectively, with 5 - $\mu \mathrm{m}$ particles. Chromatography results were processed using Star Chromatography Workstation software (version 5.0; Varian).

For OTA detection, the mobile phase consisted of methanol, water and acetic acid (70:30:2) with a flow rate of $0.5 \mathrm{~mL} / \mathrm{min}$. Detector wavelengths were set at $\lambda_{\mathrm{ex}} 336$ and $\lambda_{\text {em }} 464$. OTA was identified by constant retention time and quantified by comparison with peak areas of spiked samples. For the calibration curve, OTA-free plasma and kidney homogenates were spiked with a known amount of OTA and were cleaned up as samples. OTA-positive samples were confirmed by adding a known amount of standard OTA solution.

\section{Preparation of kidney tissue homogenate for} the comet assay

Tissue samples were homogenized in chilled homogenization buffer, $\mathrm{pH} 7.5$, containing $75 \mathrm{mM} \mathrm{NaCl}$ and $24 \mathrm{mM} \mathrm{Na}_{2}$ EDTA to obtain a $10 \%$ tissue solution. A Pottertype homogenizer was used, and kidney samples were kept on ice during and after homogenization (12).

\section{Alkaline comet assay}

We used a modified alkaline comet assay protocol according to Sasaki et al. (12). Six microliters of kidney homogenate was suspended on $0.5 \%$ low-melting agarose and sandwiched between a layer of $0.6 \%$ normal-melting agarose and a top layer of $0.5 \%$ low melting agarose on fully frosted slides. The slides were kept on ice during the polymerization of each gel layer. After the solidification of the $0.6 \%$ agarose layer, the slides were immersed in a lysis solution (1\% sodium sarcosinate, $2.5 \mathrm{M} \mathrm{NaCl}, 100 \mathrm{mM}$ $\mathrm{Na}_{2}$ EDTA, $10 \mathrm{mM}$ Tris-HCl, $1 \%$ Triton $\mathrm{X}$ 100 , and $10 \%$ DMSO) at $4^{\circ} \mathrm{C}$. After $1 \mathrm{~h}$, the slides were placed in electrophoresis buffer (0.3 M NaOH, $1 \mathrm{mM} \mathrm{Na} 2$ EDTA, $\mathrm{pH} 13$ ) for $10 \mathrm{~min}$ at $0^{\circ} \mathrm{C}$ to allow DNA to unwind. Electrophoresis was performed for $10 \mathrm{~min}$ at $300 \mathrm{~mA}$ and $1 \mathrm{~V} / \mathrm{cm}$. The slides were neutralized with Tris- $\mathrm{HCl}$ buffer, $\mathrm{pH} 7.5$, and stained with $20 \mu \mathrm{g} / \mathrm{mL}$ ethidium-bromide for $10 \mathrm{~min}$. Each slide was analyzed using the Leitz Orthoplan (Wetzlar, Germany) epifluorescence microscope. One hundred cells were analyzed on each slide using the comet assay II automatic digital analysis system (Perceptive Instruments Ltd., Halstead, Suffolk, UK) to determine tail length and tail intensity. Tail length $(\mu \mathrm{m})$ is the distance of DNA migration from the center of the body of the nuclear core and is used to evaluate the extent of DNA damage. Tail intensity $(\%)$ is the percentage of the genomic DNA that migrates during electrophoresis from the nuclear core to the tail. Both tail length and tail intensity are measured automatically by image analysis software. Tail moment was calculated according to the following formula: tail moment $=$ tail length $\mathrm{x}$ tail intensity/100 (12). According to Robbiano et al. (8), data are shown as DNAdamaging potency (comet assay endpoint treated - comet assay endpoint control)/OTA concentration $\mu \mathrm{M}$ ).

\section{Statistical analysis}

Possible differences in the comet assay 
endpoints between the kidney samples from control and treated rats were determined by the non-parametric Kruskal-Wallis test. The same statistical method was used to estimate the significance of differences between different treatment durations. Probability values of $\mathrm{P}<0.05$ were considered to be statistically significant.

The correlation between doses of OTA in kidney homogenates and comet assay endpoints was tested using the linear regression analysis.

\section{Results}

During the experiment there were no

Table 1. Concentrations of ochratoxin A in plasma and kidney of rats receiving ochratoxin A (ip, $0.5 \mathrm{mg} \mathrm{kg}$ body weight $^{-1}$ day $^{-1}$ ) for 7,14 and 21 days.

\begin{tabular}{lcc}
\hline \multirow{2}{*}{ Length of treatment (days) } & \multicolumn{2}{c}{ Concentration of ochratoxin A } \\
\cline { 2 - 3 } & Plasma $(\mu \mathrm{g} / \mathrm{mL})$ & Kidney $(\mu \mathrm{g} / \mathrm{g})$ \\
\hline 7 & $4.86 \pm 0.53$ & $0.87 \pm 0.09$ \\
14 & $7.52 \pm 3.32$ & $0.99 \pm 0.06$ \\
21 & $7.85 \pm 2.24$ & $1.09 \pm 0.15$
\end{tabular}

Data are reported as means \pm SD for 5 animals in each group.

Table 2. Tail length, tail intensity (\% of total genomic DNA found in the tail of the comets), and tail moment (tail length $x$ tail intensity/100) measured with comet assay in kidney cells of animals treated with ochratoxin $\mathrm{A}$.

\begin{tabular}{llll}
\hline \multirow{2}{*}{ Length of treatment } & \multicolumn{3}{c}{ DNA damaging potency } \\
\cline { 2 - 4 } & Tail length & Tail intensity & Tail moment \\
\hline $\begin{array}{c}\text { Negative control } \\
\quad(1.0 \mathrm{~mL} / \mathrm{kg} \mathrm{Tris-buffer})\end{array}$ & $0.0 \pm 0.36$ & $0.0 \pm 0.15$ & $0.0 \pm 0.04$ \\
7 days & $1.38 \pm 0.66^{*}$ & $0.98 \pm 0.23^{*}$ & $0.4 \pm 0.29^{*}$ \\
14 days & $2.60 \pm 0.52^{*+}$ & $1.22 \pm 0.30^{*}$ & $0.6 \pm 0.12^{*+}$ \\
21 days & $5.70 \pm 0.50^{*+\#}$ & $2.52 \pm 0.34^{*+\#}$ & $0.8 \pm 0.12^{*+\#}$ \\
$\begin{array}{c}\text { Positive control (40 mg/kg } \\
\text { methyl methanesulfonate) }\end{array}$ & $3.80 \pm 0.43^{*}$ & $2.44 \pm 0.39^{*}$ & $0.6 \pm 0.16^{*}$ \\
& & & \\
\hline
\end{tabular}

Data are reported for kidney cells from control animals as the mean for all three time points $(\mathrm{N}=15)$ and from animals treated with $0.5 \mathrm{mg}$ ochratoxin $\mathrm{A}(\mathrm{OTA}) / \mathrm{kg}$ body weight for 7,14 and 21 days ( $N=5$ in each group). Data are reported as means \pm SEM (endpoint value treated animals - endpoint value corresponding control)/OTA, 1.23 $\mu \mathrm{M})$.

${ }^{*} \mathrm{P}<0.05$ compared to control; ${ }^{+} \mathrm{P}<0.05$ compared to 7 -day treatment; ${ }^{*} \mathrm{P}<0.05$ compared to 14-day treatment group (non-parametric Kruskal-Wallis test). changes in body or kidney weight of OTAtreated rats compared to negative control animals.

The OTA concentrations in plasma ( $\mu \mathrm{g} /$ $\mathrm{mL}$ ) and kidney homogenate ( $\mu \mathrm{g} / \mathrm{g}$ tissue) of treated animals are reported as means \pm SD (Table 1). During the experiment, OTA concentrations in plasma and kidney tissue increased steadily.

We assessed the time course of OTA genotoxicity in the kidney of treated animals using the comet assay as a highly effective tool for the biomonitoring of DNA integrity. In all OTA-treated groups $(0.5 \mathrm{mg} \mathrm{kg}$ body weight $^{-1}$ day $^{-1}$ for 7,14 , and 21 days), the tail length in kidney tissue was significantly higher than in controls $(\mathrm{P}<0.05$; Table 2). Tail length in animals treated for 7,14 , and 21 days increased with the length of treatment, and the difference between all groups was significant $(P<0.05)$. Tail intensity in kidney cells of all treated groups was higher than in controls $(\mathrm{P}<0.05$; Table 2$)$. The highest tail intensity was observed in animals treated for 21 days, and the difference was significant in respect to animals treated for 7 and 14 days $(\mathrm{P}<0.05)$. Tail moment also increased with the length of treatment, with significant differences between all groups $(\mathrm{P}<0.05$; Table 2$)$.

\section{Discussion}

The genotoxic properties of OTA have been previously tested using the comet assay on Madin-Darby canine kidney (MDCK) cells, human fibroblasts, and human-derived hepatoma (HepG2) cells (13-15). OTA induced single-strand breaks in MDCK and HepG2 cells in a concentration-dependent manner, while in human fibroblasts it caused DNA breaks in a time- and dose-dependent manner. The increase in all comet assay endpoints observed in the present study agrees with DNA strand breaks detected with the comet assay in the above mentioned in vitro studies. 
OTA is undoubtedly a carcinogenic compound that causes tumors in rat kidneys (3). Until now, evidence of OTA genotoxicity in vivo was obtained mostly by measuring DNA adducts in the kidneys of mice and rats using the ${ }^{32} \mathrm{P}$-post-labeling method $(6,7)$. While some investigators claim that OTA binds covalently to DNA, forming OTA-DNA adducts (16), others used a very sensitive method (liquid chromatography/mass spectrometry/mass spectrometry) to show that DNA binding of OTA in exposed rats cannot be detected and is unlikely to reveal the mechanism of OTA toxicity (17).

Robbiano et al. (8) were the first to report OTA genotoxicity based on tests using alkaline single-cell gel electrophoresis in the rat kidney. The statistically significant increase in the average frequency of DNA breaks and/or alkali labile sites was obtained with a very high single OTA dose $(10 \mathrm{mg} / \mathrm{kg}$ body weight, that is $1 / 2$ LD50). In the present study, $0.5 \mathrm{mg}$ OTA $\mathrm{kg}$ body weight ${ }^{-1} \mathrm{day}^{-1}$ for 7 days was sufficient to significantly increase the tail length and intensity in the kidney of experimental animals. Significant differences in tail length, tail intensity and tail moment between 7 and 21 days of treatment indicate that these lesions are time dependent.

When tested using linear regression anal- ysis, OTA concentration in kidney tissue showed a high positive correlation with tail length, tail intensity and tail moment. OTA concentration was found to correlate more strongly with tail intensity $\left(\mathrm{r}^{2}=0.9936, \mathrm{P}=\right.$ $0.02)$ and tail moment $\left(\mathrm{r}^{2}=0.9874, \mathrm{P}=0.02\right)$ than with tail length $\left(\mathrm{r}^{2}=0.8679, \mathrm{P}=0.24\right)$. These results are expected because, during electrophoresis, DNA does not migrate as fragments. The tail of the comet is the result of the migration of relaxed DNA loops that are pulled by the electric field to a limited distance from the core. The length of these loops determines the length of the comet tail. Since tail intensity indicates the number of DNA breaks, it is assumed that beyond some critical amount of damage, what increases is tail intensity rather than tail length (18).

The present study confirms the genotoxicity of OTA reported in earlier studies on cell cultures and on experimental animals. The genotoxicity of OTA found in our study is consistent with its carcinogenic potential in the kidney of experimental animals.

\section{Acknowledgments}

We wish to thank Mrs. Jasna Mileković, Mrs. Marija Kramarić, and Mrs. Mirjana Matašin for technical assistance.

\section{References}

1. Speijers GJA, van Egmond $H$. Worldwide ochratoxin $A$ levels in food and feeds. In: Creppy EE, Castegnaro M, Dirheimer G (Editors), Human ochratoxicosis and its pathologies. Paris: John Libbey Eurotox Ltd.; 1993. p 85-100.

2. Krogh P. Mycotoxin porcine nephropathy: a possible model for Balkan endemic nephropathy. Second International Symposium on Endemic Nephropathy. 1974 March 25-31; Sofia. 1974.

3. Boorman GA. Technical Report on the Toxicology and Carcinogenesis Studies of Ochratoxin A in F344/N Rats. Durham: Research Triangle Park, National Institute of Health; 1989.

4. IPCS. WHO Food Additives Series. Safety evaluation of certain mycotoxins in food. Geneva: World Health Organization; 2001.

5. Robbiano L, Carrozzino R, Bacigalupo M, Corbu C, Brambilla G. Correlation between induction of DNA fragmentation in urinary bladder cells from rats and humans and tissue-specific carcinogenic activity. Toxicology 2002; 179: 115-128.

6. Pfohl-Leszkowicz A, Chakor K, Creppy EE, Dirheimer G. DNA ad- duct formation in mice treated with ochratoxin A. In: Castegnaro M, Pleština R, Dirheimer G, Chernozemsky IN, Bartsch H (Editors), Mycotoxins, endemic nephropathy and urinary tract tumours. Lyon: IARC Scientific Publications No. 115. International Agency for Research on Cancer; 1991. p 245-253.

7. Petkova-Bocharova T, Stoichev II, Chernozemsky IN, Castegnaro $\mathrm{M}$, Pfohl-Leszkowicz A. Formation of DNA adducts in tissues of mouse progeny through transplacental contamination and/or lactation after administration of a single dose of ochratoxin $A$ to the pregnant mother. Environ Mol Mutagen 1998; 32: 155-162.

8. Robbiano L, Baroni D, Carrozzino R, Mereto E, Brambilla G. DNA damage and micronuclei induced in rat and human kidney cells by six chemicals carcinogenic to the rat kidney. Toxicology 2004; 204: 187-195.

9. Bondy G, Suzuki C, Barker M, Armstrong C, Fernie S, Hierlihy L, et al. Toxicity of fumonisin B1 administered intraperitoneally to male Sprague-Dawley rats. Food Chem Toxicol 1995; 33: 653-665. 
10. Peraica M, Domijan AM, Fuchs R, Lucic A, Radic B. The occurrence of ochratoxin A in blood in general population of Croatia. Toxicol Lett 1999; 110: 105-112.

11. Bauer J, Gareis M, Gedek B. Determination and occurrence of ochratoxin A in slaughtered swine. Berl Munch Tierarztl Wochenschr 1984; 97: 279-283.

12. Sasaki YF, Nishidate E, Izumiyama F, Matsusaka N, Tsuda S. Simple detection of chemical mutagens by the alkaline single-cell gel electrophoresis (Comet) assay in multiple mouse organs (liver, lung, spleen, kidney, and bone marrow). Mutat Res 1997; 391: 215231.

13. Lebrun S, Follmann W. Detection of ochratoxin A-induced DNA damage in MDCK cells by alkaline single cell gel electrophoresis (comet assay). Arch Toxicol 2002; 75: 734-741.

14. Russo A, La Fauci L, Acquaviva R, Campisi A, Raciti G, Scifo C, et al. Ochratoxin A-induced DNA damage in human fibroblast: protec- tive effect of cyanidin 3-O-beta-d-glucoside. J Nutr Biochem 2005; 16: 31-37.

15. Ehrlich V, Darroudi F, Uhl M, Steinkellner H, Gann M, Majer BJ, et al. Genotoxic effects of ochratoxin A in human-derived hepatoma (HepG2) cells. Food Chem Toxicol 2002; 40: 1085-1090.

16. Faucet V, Pfohl-Leszkowicz A, Dai J, Castegnaro M, Manderville RA. Evidence for covalent DNA adduction by ochratoxin A following chronic exposure to rat and subacute exposure to pig. Chem Res Toxicol 2004; 17: 1289-1296.

17. Mally A, Zepnik H, Wanek P, Eder E, Dingley K, Ihmels $H$, et al. Ochratoxin A: lack of formation of covalent DNA adducts. Chem Res Toxicol 2004; 17: 234-242.

18. Collins AR, Dobson VL, Dusinska M, Kennedy G, Stetina R. The comet assay: what can it really tell us? Mutat Res 1997; 375: 183193. 